\title{
Trophic position of coexisting krill species: a stable isotope approach
}

\author{
Mette Dalgaard Agersted ${ }^{1, *}$, Antonio Bode ${ }^{2}$, Torkel Gissel Nielsen ${ }^{1,3}$ \\ ${ }^{1}$ National Institute of Aquatic Resources, Section for Marine Ecology and Oceanography, Technical University of Denmark, \\ Kavalergården 6, 2920 Charlottenlund, Denmark \\ ${ }^{2}$ Instituto Español de Oceanografía, Centro Oceanográfico de A Coruña, Apdo. 130, 15080 A Coruña, Spain \\ ${ }^{3}$ Greenland Climate Research Centre, Greenland Institute of Natural Resources, Box 570, 3900 Nuuk, Greenland
}

\begin{abstract}
Four krill species with overlapping functional biology coexist in Greenland waters. Here, we used stable isotopes to investigate and discuss their trophic role and mode of coexistence. Bulk carbon $\left(\delta^{13} \mathrm{C}\right)$ and nitrogen $\left(\delta^{15} \mathrm{~N}\right)$ stable isotope analyses of Thysanoessa longicaudata, T. inermis, T. raschii and Meganyctiphanes norvegica sampled in June 2010 in Godthåbsfjord, SW Greenland, revealed new insight into the species' trophic roles and positions. There was a general positive correlation between body length and trophic position. The largest species, $M$. norvegica, had the highest trophic position (TP $[$ mean $\pm \mathrm{SE}]=2.8 \pm 0.2$ ) indicating carnivory, while T. inermis ( $\mathrm{TP}=2.4 \pm 0.3$ ) had a more omnivorous diet. In turn, $T$. longicaudata and T. raschii $(\mathrm{TP}=$ $2.2 \pm 0.2)$ were herbivorous. Along the fjord, plankton composition affected trophic position. T. longicaudata was more omnivorous offshore than inshore, where it had the same trophic position as the baseline primary consumer Calanus spp. Similarly, T. raschii and T. inermis had higher trophic positions in the mouth of the fjord compared with the inner fjord. Regardless of spatial variations in potential food and the overlap in diet, typical of opportunistic species, body size appears as the key factor determining the role and position of krill in the food web.
\end{abstract}

KEY WORDS: Thysanoessa spp. $\cdot$ Meganyctiphanes norvegica $\cdot$ Carbon stable isotope $\cdot \delta^{13} \mathrm{C} \cdot$ Nitrogen stable isotope $\cdot \delta^{15} \mathrm{~N} \cdot$ Sub-Arctic $\cdot$ Food web

\section{INTRODUCTION}

Krill are important vectors in the Arctic marine food web, channelling primary production to upper trophic levels (Mauchline \& Fisher 1969, Onsrud et al. 2004, Rosing-Asvid et al. 2013). Furthermore, krill contribute to the biological pump through production of fast-sinking faecal pellets (Mauchline \& Fisher 1969). In Greenland coastal waters, 4 krill species coexist (Agersted \& Nielsen 2014). However, knowledge of niche partitioning and the trophic position of the coexisting species is lacking.

Hutchinson (1961) discusses 'the paradox of the plankton' and questions how phytoplankton species, competing for the same resources, are able to coexist. In accordance with 'the competitive exclusion princi- ple' (Hardin 1960), it would be expected that in a homogeneous environment one species would outcompete all others, thereby leading to a population of a single species. However, in many cases this is not true, and factors such as size-selective grazing (Wiggert et al. 2005) and spatio-temporal heterogeneity (Miyazaki et al. 2006) have been suggested to help resolve the paradox by enabling coexistence and hereby to determine the fate of a given population. The 3 copepod species Calanus finmarchicus, C. glacialis and C. hyperboreus provide an example of coexistence in northern ecosystems (Conover 1988, Falk-Petersen et al. 2009). They all exploit the same size range of plankton (Levinsen et al. 2000), but have different phenology (Falk-Petersen et al. 2009), which could be the main factor making coexistence possible. 
Krill have a broader prey-size spectrum than copepods, and are capable of exploiting several trophic levels (Boyd et al. 1984, McClatchie 1985, Barange et al. 1991, Agersted et al. 2011). The fact that krill are generalists could be a key trait that resolves 'the paradox' for this group as this means that interspecific food competition is reduced. A prerequisite for interspecific competition to occur between sympatric congeners such as krill is food scarcity; therefore, if food is in excess, competition for resources will be irrelevant.

A standard approach for investigating the preysize spectrum and trophic position of zooplankton is bottle grazing experiments, where the experimental results also can be extrapolated to grazing impacts in situ. However, the limitation of these experiments is that they only represent a snapshot in time: They do not reflect the in situ prey variability in time and space because the experimental animals are unable to display migratory behaviour within the confines of a bottle.

Analysis of gut content or faecal pellet composition is another approach to investigate krill feeding (e.g. González 1992, Karlson \& Båmstedt 1994, Schmidt et al. 2003). However, this method only provides snapshot information of recently ingested prey and is biased towards prey with an exoskeleton, such as larger zooplankton, and thus underestimates or ignores soft-bodied prey (Båmstedt et al. 2000).

Stable isotope analysis provides an alternative and complimentary method for determining trophic position (Peterson \& Fry 1987, Fry 1988, Hobson \& Welch 1992). This method gives a time-integrated average trophic position of a given species, since the heavier isotopes accumulate from prey to predator over time (Fry \& Sherr 1984, Fry 1988). Stable nitrogen isotope $\left(\delta^{15} \mathrm{~N}\right)$ values provide an estimate of the trophic position of a consumer (Vander Zanden \& Rasmussen 2001), whereas carbon isotope $\left(\delta^{13} C\right)$ values can be used as a proxy for the source of primary production, and the inshore and benthic versus offshore and pelagic feeding preferences of a consumer (Hobson et al. 1994, France 1995). Previous studies have investigated stable isotopes in krill around Svalbard (Søreide et al. 2006, Søreide et al. 2013), Iceland (Petursdottir et al. 2008, 2012) and Greenland (Holst Hansen et al. 2012). However, these studies only investigate a specific area and do not look at spatial differences in stable isotopes among species present. Because isotope signals at the base of the food web vary at spatial scales (e.g. Holst Hansen et al. 2012), studies considering spatial differences in stable isotopes provide insights into the origin of nutrients as well as into the local variability of feeding preferences.

Godthåbsfjord is a sub-Arctic sill fjord located in SW Greenland. The fjord is formed by several branches forming a complex system where the head of the main fjord drains 3 glaciers from the Greenland Ice Sheet (Mortensen et al. 2011). Outside the fjord, off the coast of Greenland, the West Greenland Current brings warm and saline water of Atlantic and polar origin (Sutherland \& Pickart 2008, Mortensen et al. 2011), whereas the fjord itself is influenced by freshwater runoff from glaciers (Mortensen et al. 2011). The plankton composition in the fjord is affected by the oceanographic regimes, and varies along the fjord (Arendt et al. 2010, Calbet et al. 2011, Tang et al. 2011, Agersted \& Nielsen 2014). The distribution of krill species in Godthåbsfjord during summer was studied in detail by Agersted \& Nielsen (2014). In the offshore area, the Atlantic species Thysanoessa longicaudata dominates, whereas the fjord is dominated by the arcto-boreal T. raschii and T. inermis. The boreal Meganyctiphanes norvegica is transported into the fjord by advection from offshore waters, and is found in the inner part of Godthåbsfjord (Agersted \& Nielsen 2014). These 4 species are all considered omnivorous and feed on different prey items depending on season and availability (Mauchline \& Fisher 1969, Berkes 1976, Sargent \& Falk-Petersen 1981, FalkPetersen et al. 2000, Schmidt 2010).

The objectives of the present study were to (1) analyse the spatial trend in stable isotopes in krill species along the Godthåbsfjord, from the offshore area to the glacier, in relation to nutrient sources, and (2) determine the trophic position of the krill species in the different regions of the fjord.

\section{MATERIALS AND METHODS}

\section{Nutrients and chlorophyll a}

The sampling was carried out from R/V 'Dana' (National Institute of Aquatic Resources, DTU Aqua) during a cruise from 6 to 24 June 2010. The sampling took place from the offshore waters (Fyllas Bank, FB) throughout the main branch of Godthåbsfjord (GF) (Fig. 1). Stations located in 2 side branches were also included in the sampling (Umanap, U; Kapisidglit, $\mathrm{K}_{\text {; }}$ Fig. 1). Water samples for analysis of inorganic nutrients (phosphate, nitrate, ammonia and silicate) and chlorophyll a (chl a) were collected at several depths. Water samples for chl a analysis were filtered onto $\mathrm{GF} / \mathrm{F}$ filters and extracted and preserved in $96 \%$ 


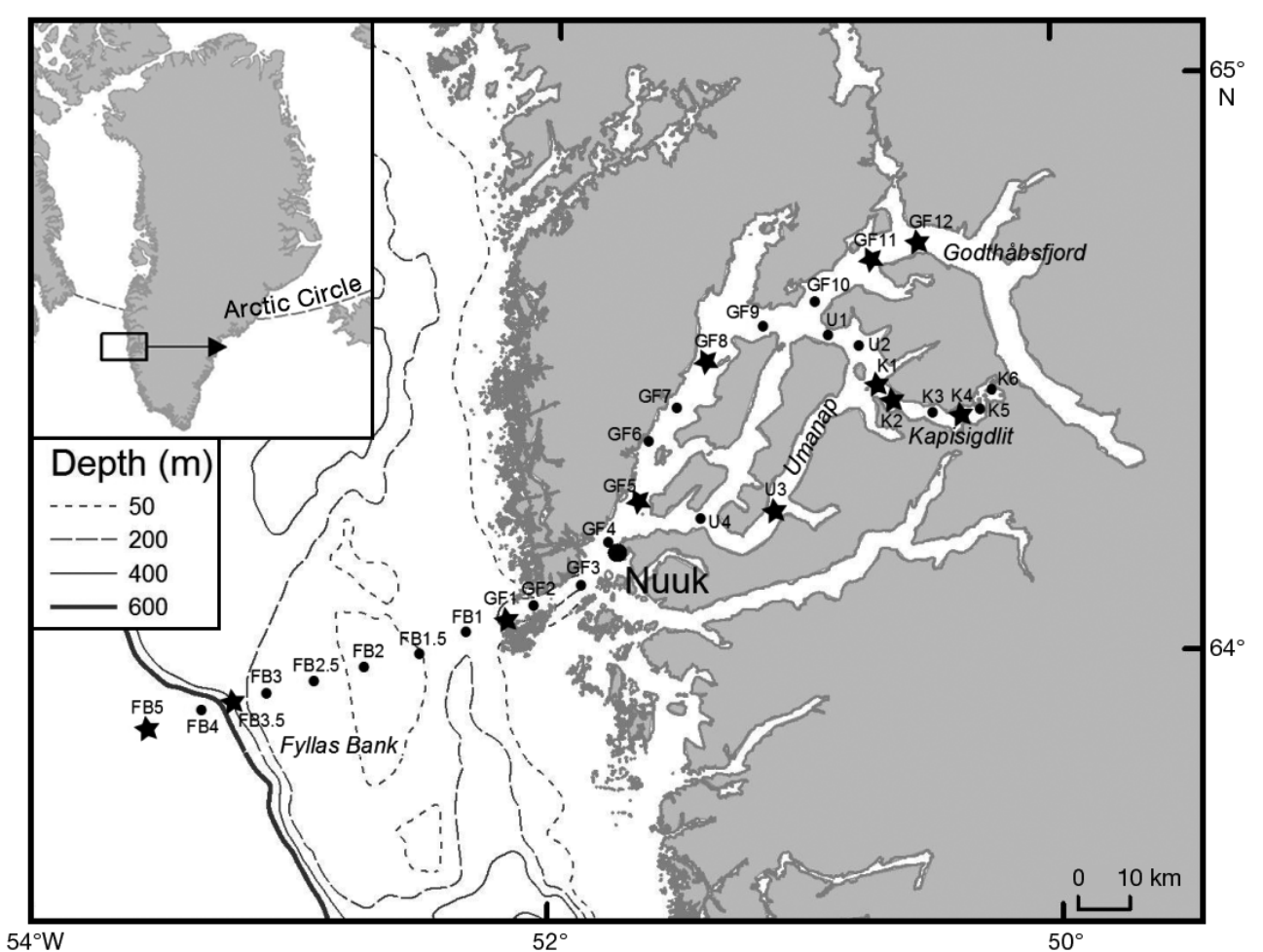

Fig. 1. Location of sampling stations in Godthåbsfjord, SW Greenland. Station abbreviations: $\mathrm{FB}=$ Fyllas Bank; GF = Godthåbsfjord; $\mathrm{K}$ = Kapisigdlit; $\mathrm{U}=$ Umanap. Stars indicate stations where specimens were analysed for stable isotopes ethanol for 12 to $24 \mathrm{~h}$ (Jespersen \& Christoffersen 1987). Chl a was analysed using a fluorometer (TD700, Turner Designs) calibrated against a pure chl a standard (Turner Designs). Water samples for inorganic nutrient analysis were immediately frozen $\left(-20^{\circ} \mathrm{C}\right)$ for later analysis on a Skalar autoanalyser (Breda), following the procedures of Hansen \& Koroleff (1999). Nutrient sample precisions were $0.06,0.1$, 0.3 and $0.2 \mu \mathrm{M}$ for phosphate, nitrate, ammonia and silicate, respectively.

\section{Zooplankton sampling}

Due to their diel vertical migration, krill were sampled at night in the upper $140 \mathrm{~m}$ with oblique hauls using a $2 \mathrm{~m}$ MIK ring net (black, mesh size $1500 \mu \mathrm{m}$ ) at a vessel speed of $2.8 \pm 0.9$ knots (mean $\pm \mathrm{SD}, \mathrm{n}=$ 44). Samples were preserved in buffered formalin ( $4 \%$ final concentration).

\section{Stable isotope analysis}

Four species of krill (Thysanoessa longicaudata, $T$. inermis, T. raschii and Meganyctiphanes norvegica; not gender differentiated) and copepods of the genus Calanus (females of C. finmarchicus, C. glacialis and C. hyperboreus) preserved in formalin ( $>1 \mathrm{yr}$ storage) were collected for stable isotope analysis (see Fig. 1 for stations). Krill and Calanus spp. originated from the same samples. For krill, 3 individuals (i.e. 3 replicates) of each species and year class (specimens of similar size were assumed to represent the same year class) were sorted and length was measured from rostrum to end of telson to the nearest mm. For Calanus spp., 5 individuals of similar size were pooled (prosome length measured to the nearest $\mu \mathrm{m}$ for all), with 3 replicates per station. Both krill and Calanus spp. were washed with filtered sea water and dried at $60^{\circ} \mathrm{C}$ for $48 \mathrm{~h}$. Krill were then powdered to homogenise the muscle tissue. Trials of muscle aliquots were compared with whole-body samples for at least 3 individuals of each species (except for T. longicaudata due to smaller size) to investigate whether there was a difference in isotope signal (Schmidt et al. 2004). Stable isotope analyses (carbon and nitrogen) were performed on an elemental analyser coupled to an Isotope Ratio Mass Spectrometer (EA-IRMS) and the variables $\% \mathrm{~N}$, $\% \mathrm{C}$ (by dry mass), C:N (molar), $\delta^{15} \mathrm{~N}$ and $\delta^{13} \mathrm{C}(\%)$ were determined as described in Bode \& Alvarez-Ossorio (2004). The precision of isotope determinations (standard error of 3 replicates) was 0.06 and $0.12 \%$, for $\delta^{15} \mathrm{~N}$ and $\delta^{13} \mathrm{C}$, respectively. As they were used for internal comparisons within the study, isotopic values were not corrected for the small effect caused by formalin (Sarakinos et al. 2002, Bicknell et al. 2011). However, the resulting values are not directly compa- 
rable with values for unpreserved samples reported in the literature. Similarly, no corrections were applied for the small depletion in $\delta^{13} \mathrm{C}$ caused by lipids (Schmidt et al. 2003), as C:N values of all species analysed were near the lower limits of the ranges reported in the literature (Schmidt et al. 2003, Kiørboe 2013) and thus indicated low lipid content.

\section{Estimation of trophic position of krill}

We used Calanus spp. as the isotopic reference baseline, as in previous studies (Søreide et al. 2006, Petursdottir et al. 2008, 2012, Holst Hansen et al. 2012), assuming herbivorous diet during the spring bloom (Søreide et al. 2008). We did not distinguish between the 3 species Calanus finmarchicus, $C$. glacialis and C. hyperboreus but analysed individuals of a homogenous size throughout the study area (mean length $=2.95 \mathrm{~mm}, \mathrm{SD}=0.38, \mathrm{n}=188$ ) to ensure that they were grazing on similar prey during the study period.

The trophic position of krill $\left(\mathrm{TP}_{\text {krill }}\right)$ was calculated from $\delta^{15} \mathrm{~N}$ values (after Vander Zanden \& Rasmussen 2001) using Calanus as the primary consumer:

$$
\mathrm{TP}_{\text {krill }}=\frac{\delta^{15} \mathrm{~N}_{\text {krill }}-\delta^{15} \mathrm{~N}_{\text {Calanus }}}{\Delta \delta^{15} \mathrm{~N}}+\mathrm{TP}_{\text {Calanus }}
$$

where $\delta^{15} \mathrm{~N}_{\text {krill }}$ is the measured $\delta^{15} \mathrm{~N}$ value in the krill, $\delta^{15} \mathrm{~N}_{\text {Calanus }}$ is the $\delta^{15} \mathrm{~N}$ value measured in Calanus in the same area as that for the krill, $\mathrm{TP}_{\text {Calanus }}$ is the trophic position of Calanus assuming a herbivorous diet $\left(\mathrm{TP}_{\text {Calanus }}=2 ;\right.$ Hobson \& Welch 1992, Søreide et al. 2006, 2008) and $\Delta \delta^{15} \mathrm{~N}$ is the mean trophic enrichment factor of $\delta^{15} \mathrm{~N}(=3.4 \%$; Vander Zanden \& Rasmussen 2001, Post 2002, Søreide et al. 2006). Mean $\mathrm{TP}_{\text {krill }}$ values were computed using mean $\delta^{15} \mathrm{~N}$ values measured at each station. Standard error of the estimates was computed by propagation of errors of mean $\delta^{15} \mathrm{~N}$ values.

Computed trophic positions were classified as representing herbivory $(\mathrm{TP} \leq 2.3)$, omnivory $(\mathrm{TP}=$ 2.4-2.7) and carnivory ( $\mathrm{TP}=\geq 2.8$ ) (after Søreide et al. 2013).

To estimate $\mathrm{TP}$, we did not correct for possible effects due to formalin on $\delta^{15} \mathrm{~N}$, as both Calanus and krill samples were preserved in the same way. Other studies have shown that formalin preservation may cause small losses of light isotopes for plankton, but the effect is often undetectable for nitrogen (Sarakinos et al. 2002, Bicknell et al. 2011) and did not prevent further analysis of the trophic structure (Rau et al. 2003, Chiba et al. 2012).

\section{Potential krill food}

For evaluation of the trophic position of the krill in the different fjord regions, the potential food available for the krill was estimated as a reference. The total potential food was composed of heterotrophic (copepod nauplii and small and large copepods) and autotrophic (phytoplankton $>10 \mu \mathrm{m}$ ) prey, as cells $<10 \mu \mathrm{m}$ represent the lower size limit that these krill species are able to exploit (Berkes 1976, Agersted et al. 2011, M. D. Agersted unpubl. data). Small copepods included Microsetella spp., Pseudocalanus spp., Onchaea spp. and Oithona similis, whereas large copepods were represented by $C$. finmarchicus, $C$. glacialis, C. hyperboreus and Metridida longa. Nauplii included all copepod nauplii stages I to VI. Copepods were copepodite stages I to VI. The data were sampled during the same cruise as for krill, and data on mesozooplankton originates from Swalethorp et al. (2014).

\section{Data analysis}

Differences in mean values of $\% \mathrm{~N}, \% \mathrm{C}, \mathrm{C}: \mathrm{N}, \delta^{15} \mathrm{~N}$ and $\delta^{13} \mathrm{C}$ between the 4 krill species across all stations were analysed using non-parametric ANOVA (Kruskall-Wallis). Multiple comparisons between the groups were carried out using Dunnett-C post-hoc tests. Additionally, both ANOVA and Dunnett-C post-hoc tests were used to test whether there were any significant differences between stations with regard to the mean $\delta^{15} \mathrm{~N}$ and $\delta^{13} \mathrm{C}$ values (\%o) in Calanus spp. and the 4 krill species, respectively.

Differences in the analysed variables between muscle or whole-body samples were investigated using the median test on both individual and pooled krill species. To test whether body size had any effect on $\delta^{13} \mathrm{C}$ and $\delta^{15} \mathrm{~N}$ values of Calanus and krill, we used mean square regressions.

All results are presented as mean $\pm \mathrm{SE}$, unless otherwise stated. All tests were run using SPSS statistical software (v. 11.5).

\section{RESULTS}

\section{Nutrients and chlorophyll a}

The surface concentration of nitrate $(\mu \mathrm{M})$ and chl $a$ $\left(\mu \mathrm{g} \mathrm{l}^{-1}\right.$ ) varied along the fjord (Fig. 2). In general, nitrate was depleted in the surface layers and chl $a$ values were low, with 2 major exceptions: the inner part 


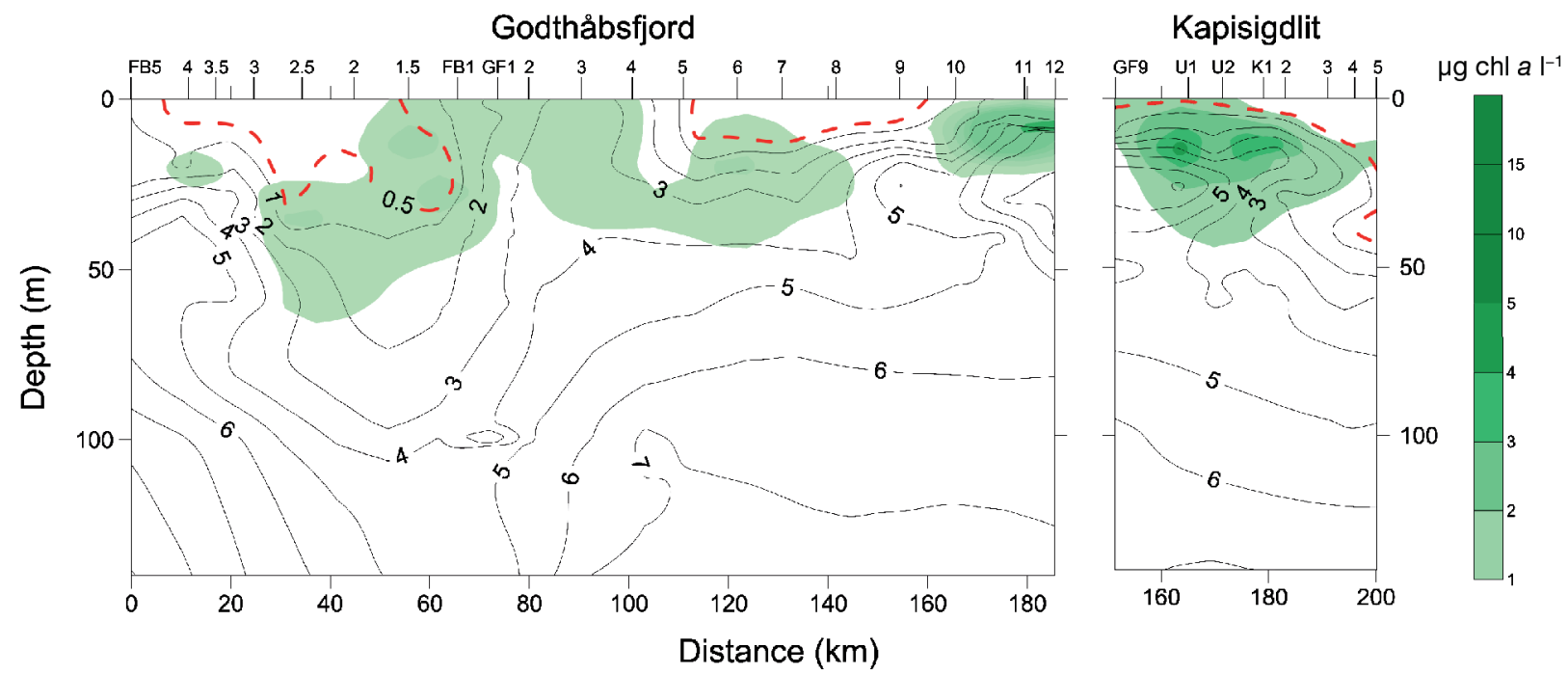

Fig. 2. Depth distribution of nitrate $(\mu \mathrm{M})$ and chlorophyll a $\left(\mu \mathrm{g} \mathrm{chl} \mathrm{a} \mathrm{l}^{-1}\right.$ ) from the offshore Fyllas Bank (FB) to the inner part of Godthåbsfjord (GF) and for Kapisigdlit (K) and Umanap (U) in the upper $140 \mathrm{~m}$ of the water column where krill were collected. Station numbers are given at the top of graph. Nitrate is displayed as contour lines with the lower detection limit $(<0.5 \mu \mathrm{M})$ indicated by the red dashed line. Chlorophyll $a$ is displayed as shaded green areas. See Fig. 1 for the location of the different stations and fjord branches

of Godthåbsfjord where upwelling made nutrients available, and the well-mixed stations in the mouth of the fjord. The inner fjord displayed nitrate concentrations up to $8 \mu \mathrm{M}$ and high chl a (up to $14 \mu \mathrm{g} \mathrm{l}^{-1}$ ) in the upper $10 \mathrm{~m}$ of the water column. In contrast, most of the main fjord basin and shelf waters displayed lower nutrient concentrations in the upper $20 \mathrm{~m}$ of the water column with correspondingly low $\mathrm{chl}$ a values. Close to the entrance of the fjord there was a noticeable increase in chl $a$ in the upper $60 \mathrm{~m}$ associated with a relative decrease in nitrate. The surface layers in the fjord branch Kapisigdlit were nitrate depleted. A subsurface bloom (up to $4 \mu \mathrm{g} \mathrm{l}^{-1}$ ) was, however, observed and was associated with the deepening of the nutricline. Ammonium concentrations (not shown) were generally low throughout the study area (up to $2 \mu \mathrm{M}$ ), while silicate and phosphate (not shown) closely followed the distribution of nitrate. Temperature and salinity data for this cruise are described by Agersted \& Nielsen (2014).

\section{Differences in body composition between species}

Among the 4 species of krill found (Meganyctiphanes norvegica, Thysanoessa inermis, T. longicaudata and T. raschii) there were no significant differences in carbon $\left(\delta^{13} \mathrm{C}\right)$ and nitrogen $\left(\delta^{15} \mathrm{~N}\right)$ between muscle or whole-body samples for the main species (T. longicaudata were too small for a reliable separation of muscle from other body parts) (Table 1). These differences were also non-significant within species (median test, $\mathrm{p}>0.05$, results not shown). Therefore, either muscle or whole-body samples were considered representative for the analysis of the variability among species or stations (median test, $\mathrm{p}>0.05$, Table 1).

Significant differences $(\mathrm{p}<0.05)$ were measured in the relative $\mathrm{C}$ and $\mathrm{N}$ content (lowest for Calanus) and C:N ratios (highest for Calanus) (Table 2). Furthermore, a marked ranking in $\delta^{13} \mathrm{C}$ and $\delta^{15} \mathrm{~N}$ values among species was found (ANOVA, p $<0.05$, Table 2). Only $T$. longicaudata had mean $\delta^{15} \mathrm{~N}$ and $\delta^{13} \mathrm{C}$ values equivalent to that of Calanus, while all other krill species had significantly higher values for both isotopes (Table 2). M. norvegica had the highest $\delta^{15} \mathrm{~N}$ values, and was clearly separated from the other species. No effect of size was found for $\delta^{13} \mathrm{C}$ and $\delta^{15} \mathrm{~N}$ when considering individual species. However, both

Table 1. Mean \pm SE $(n=$ number of samples) differences between muscle and whole-body samples in relative nitrogen $(\% \mathrm{~N})$ and carbon $(\% \mathrm{C})$ content and in natural abundance of stable nitrogen $\left(\delta^{15} \mathrm{~N}\right)$ and carbon $\left(\delta^{13} \mathrm{C}\right)$ for all krill species analysed (except for Thysanoessa longicaudata). At least 9 individuals of each species were analysed. None of the differences were significant (median test, $\mathrm{p}>0.05$ )

\begin{tabular}{|lccc|}
\hline Difference & Mean & SE & $\mathrm{n}$ \\
\hline$\% \mathrm{~N}$ & 1.25 & 0.61 & 41 \\
$\% \mathrm{C}$ & 3.32 & 2.22 & 40 \\
$\mathrm{C}: \mathrm{N}$ & -0.31 & 0.17 & 40 \\
$\delta^{15} \mathrm{~N}$ & 0.11 & 0.09 & 41 \\
$\delta^{13} \mathrm{C}$ & 0.13 & 0.11 & 40 \\
\hline
\end{tabular}


Table 2. Mean $\pm \mathrm{SE}(\mathrm{n}=$ number of samples) values of relative nitrogen $(\% \mathrm{~N})$ and carbon $(\% \mathrm{C})$ content and natural abundance of stable nitrogen $\left(\delta^{15} \mathrm{~N}\right)$ and carbon $\left(\delta^{13} \mathrm{C}\right)$ for Calanus spp. and krill. Different letters indicate significant differences between groups (i.e. species) tested by ANOVA, followed by multiple comparisons using Dunnett-C post-hoc tests, $\mathrm{p}<0.05$

\begin{tabular}{|c|c|c|c|c|}
\hline Species & Mean & SE & $\mathrm{n}$ & Group \\
\hline \multicolumn{5}{|l|}{$\% \mathrm{~N}$} \\
\hline Calanus spp. & 7.35 & 0.12 & 38 & $\mathrm{C}$ \\
\hline Meganyctiphanes norvegica & 11.25 & 0.59 & 21 & $\mathrm{a}$ \\
\hline Thysanoessa inermis & 10.59 & 0.28 & 46 & a \\
\hline Thysanoessa longicaudata & 8.72 & 0.34 & 21 & $\mathrm{~b}$ \\
\hline Thysanoessa raschii & 10.33 & 0.34 & 51 & a \\
\hline \multicolumn{5}{|l|}{$\% \mathrm{C}$} \\
\hline Calanus spp. & 38.73 & 0.78 & 38 & $\mathrm{C}$ \\
\hline Meganyctiphanes norvegica & 46.66 & 2.09 & 19 & a \\
\hline Thysanoessa inermis & 45.30 & 1.14 & 46 & $\mathrm{a}$ \\
\hline Thysanoessa longicaudata & 40.90 & 2.03 & 21 & $\mathrm{~b}$ \\
\hline Thysanoessa raschii & 42.05 & 1.38 & 51 & $\mathrm{a}$ \\
\hline \multicolumn{5}{|l|}{$\mathrm{C}: \mathrm{N}$} \\
\hline Calanus spp. & 6.23 & 0.18 & 38 & $\mathrm{a}$ \\
\hline Meganyctiphanes norvegica & 5.16 & 0.19 & 19 & $\mathrm{a}, \mathrm{b}$ \\
\hline Thysanoessa inermis & 5.12 & 0.21 & 46 & $a, b$ \\
\hline Thysanoessa longicaudata & 5.53 & 0.25 & 21 & $\mathrm{a}, \mathrm{b}$ \\
\hline Thysanoessa raschii & 4.77 & 0.07 & 51 & $\mathrm{~b}$ \\
\hline \multicolumn{5}{|l|}{$\delta^{15} \mathrm{~N}(\%)$} \\
\hline Calanus spp. & 8.40 & 0.21 & 38 & $\mathrm{~d}$ \\
\hline Meganyctiphanes norvegica & 11.36 & 0.26 & 21 & $\mathrm{a}$ \\
\hline Thysanoessa inermis & 9.89 & 0.15 & 46 & $\mathrm{~b}$ \\
\hline Thysanoessa longicaudata & 8.64 & 0.28 & 21 & $\mathrm{~d}$ \\
\hline Thysanoessa raschii & 9.19 & 0.08 & 51 & $\mathrm{C}$ \\
\hline \multicolumn{5}{|l|}{$\delta^{13} \mathrm{C}(\%)$} \\
\hline Calanus spp. & -22.89 & 0.12 & 38 & $\mathrm{~d}$ \\
\hline Meganyctiphanes norvegica & -21.99 & 0.10 & 19 & $\mathrm{~b}$ \\
\hline Thysanoessa inermis & -21.75 & 0.10 & 46 & $a, b$ \\
\hline Thysanoessa longicaudata & -22.60 & 0.15 & 21 & $\mathrm{C}$ \\
\hline Thysanoessa raschii & -21.59 & 0.07 & 51 & $\mathrm{a}$ \\
\hline
\end{tabular}

$\delta^{15} \mathrm{~N}$ and $\delta^{13} \mathrm{C}$ increased linearly with body length when considering all krill species (Fig. 3A,B), although body length explained a larger fraction of $\delta^{15} \mathrm{~N}$ compared with $\delta^{13} \mathrm{C}$.

\section{Spatial differences in stable isotopes}

Calanus spp. showed significant differences for $\delta^{13} \mathrm{C}$ and $\delta^{15} \mathrm{~N}$ among stations (Fig. 4). Stn GF12 was not significantly different from GF8 and GF11 or from K1-4 and U3. However, GF8 and GF11 were significantly different from K1-4 and U3. When considering the main branch of Godthåbsfjord, there was a significant linear increase of both $\delta^{15} \mathrm{~N}(\mathrm{r}=0.97, \mathrm{p}<0.001$, $\mathrm{n}=7)$ and $\delta^{13} \mathrm{C}(\mathrm{r}=0.85, \mathrm{p}<0.05, \mathrm{n}=7)$ values with distance from the offshore shelf to the inner part of the fjord. Inside the fjord, however, $\delta^{15} \mathrm{~N}$ values were

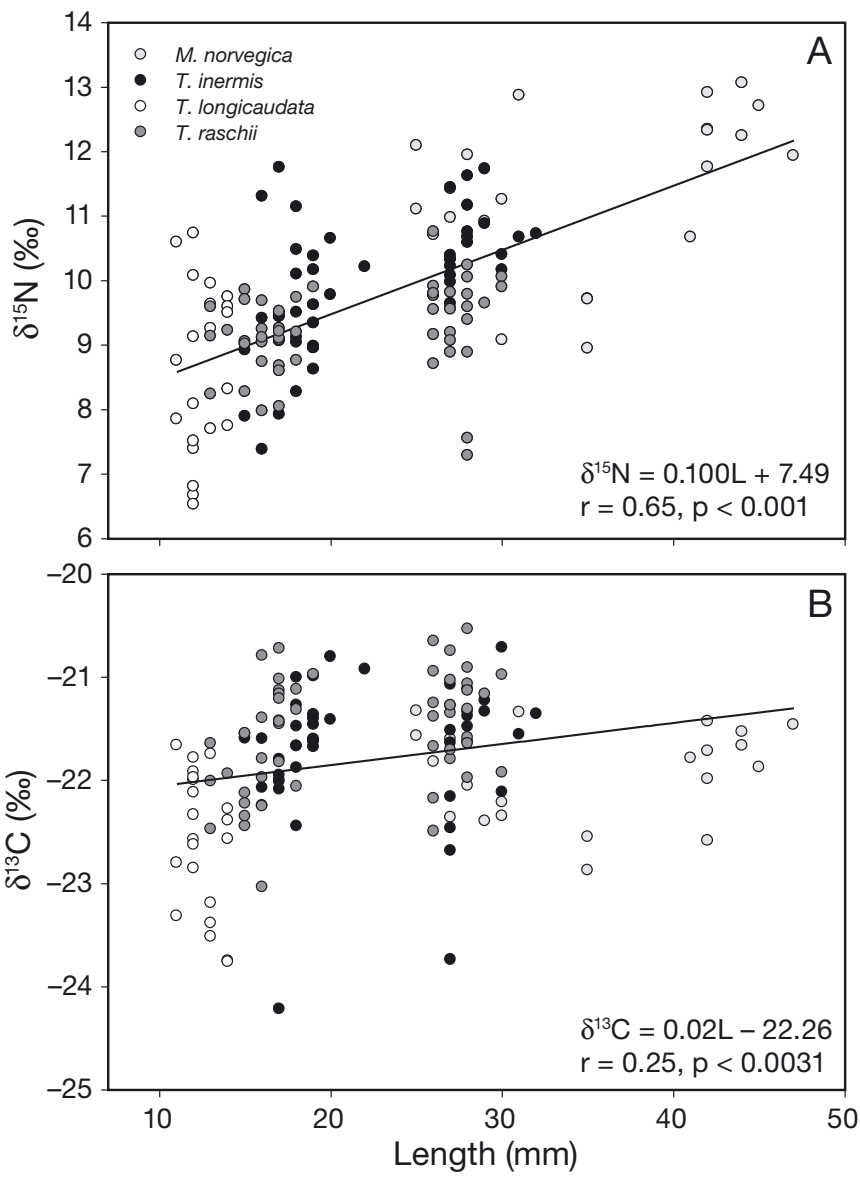

Fig. 3. Relationship between (A) $\delta^{15} \mathrm{~N}$ or (B) $\delta^{13} \mathrm{C}$ values (\%) and body length (L, mm) for krill (Meganyctiphanes norvegica, $T$. inermis, $T$. longicaudata, and T. raschii) specimens. The lines indicate the significant relationship using data for all species

comparatively less variable, while there was a large variability in $\delta^{13} \mathrm{C}$. Inside the fjord area, the highest $\delta^{15} \mathrm{~N}$ (and the lowest $\delta^{13} \mathrm{C}$ ) values occurred in the eastern branches of the fjord (Stns K1-4 and U3). This spatial pattern was less evident for krill species as some were only found at certain locations (e.g. $M$. norvegica), but in general $\delta^{15} \mathrm{~N}$ was higher and $\delta^{13} \mathrm{C}$ lower at inner fjord stations than at shelf stations (Fig. 5). When considering all krill species found in the main branch of the fjord, there was a significant linear increase in $\delta^{15} \mathrm{~N}(\mathrm{r}=0.66, \mathrm{p}<0.05, \mathrm{n}=20)$, but not in $\delta^{13} \mathrm{C}$, with distance from the shelf break.

\section{Krill trophic position and potential food}

When averaging across stations, $M$. norvegica had the highest trophic position (TP) $(2.8 \pm 0.2)$ followed by $T$. inermis $(2.4 \pm 0.1)$ and subsequently by $T$. long- 


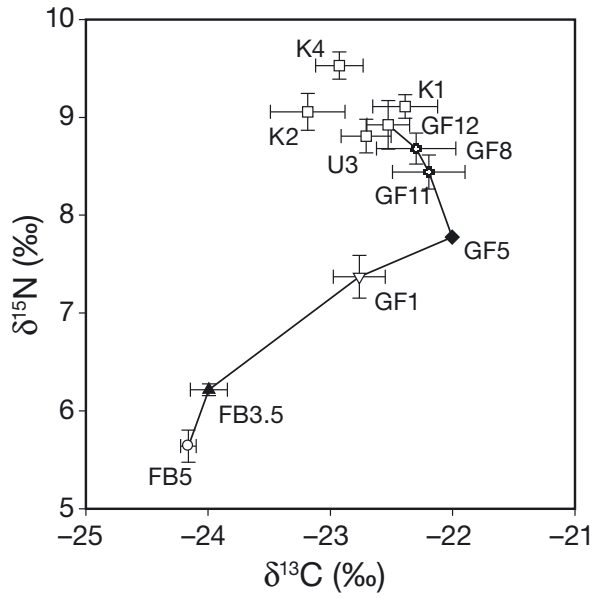

Fig. 4. Mean $( \pm \mathrm{SE}) \delta^{15} \mathrm{~N}$ and $\delta^{13} \mathrm{C}$ values (\%) for Calanus spp. The line links the values for stations in the main branch of the fjord (see Fig. 1). Different symbols indicate significant differences for $\delta^{15} \mathrm{~N}$ among stations (ANOVA and Dunnett-C post-hoc test, $\mathrm{p}<0.05)$. Only for Stns FB5 and FB3.5 were the mean $\delta^{13} \mathrm{C}$ values significantly lower than values for other stations

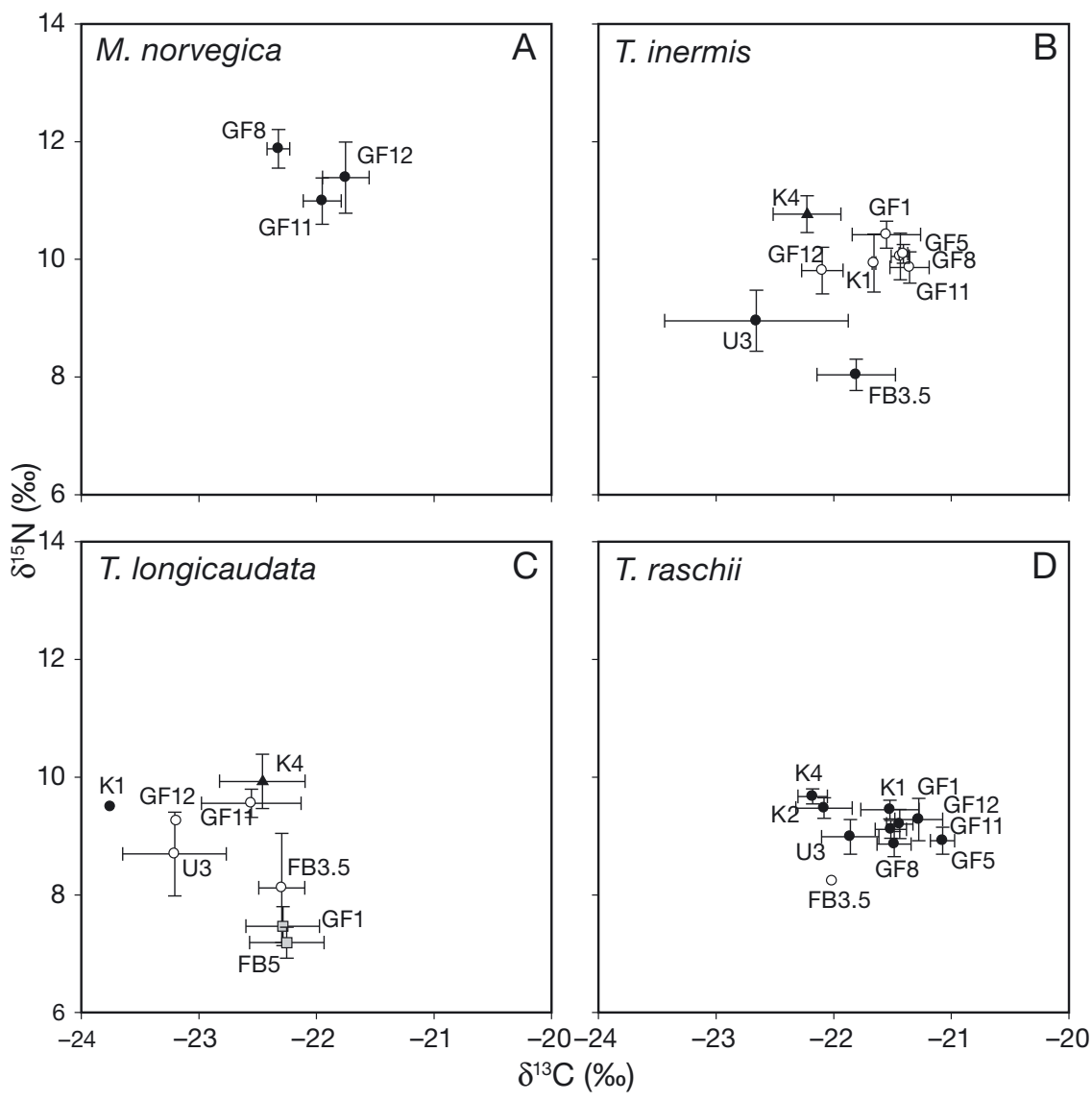

Fig. 5. Mean $( \pm \mathrm{SE}) \delta^{15} \mathrm{~N}$ and $\delta^{13} \mathrm{C}$ values (\%) for the 4 krill species (A) Meganyctiphanes norvegica, (B) Thysanoessa inermis, (C) T. longicaudata and (D) T. raschii in relation to stations (see Fig. 1). Different symbols indicate significant differences for either $\delta^{15} \mathrm{~N}$ or $\delta^{13} \mathrm{C}$ among stations (ANOVA and Dunnett-C post-hoc test, $\mathrm{p}<0.05$ ) icaudata and T. raschii, with the same trophic position $(2.2 \pm 0.2$ and $2.2 \pm 0.1$, respectively) (Fig. 6). Consequently, the trophic position of the krill species was in general above the position of Calanus spp. $(\mathrm{TP}=2)$. These differences, however, were not statistically significant because of the variability of the estimates. For instance, the TP for T. longicaudata and T. raschii was higher in the offshore area, compared with the inner part of Godthåbsfjord and the fjord branches Kapisigdlit and Umanap (Fig. 6). The same trend was observed for T. inermis at Stn GF1 where it had a similar trophic position to $M$. norvegica in the inner fjord. Trophic positions for Thysanoessa species in Kapisigdlit and Umanap were very similar between species and stations, and also similar to trophic positions in the inner Godthåbsfjord (GF8 to 12). Additionally, there was a significant linear decrease in the mean trophic position of Thysanoessa species with distance from the shelf break for the main branch of the fjord $(r=0.56, \mathrm{p}<$ $0.05, \mathrm{n}=17$ ). When $M$. norvegica was included, there was also a linear increase in fjord-averaged trophic position with size of the krill, irrespective of species, $(\mathrm{r}=0.52, \mathrm{p}<0.01, \mathrm{n}=$ 30). This result supports the fact that regardless of where the samples came from, trophic position increased krill size.

The potential food for krill was divided into different groups (Fig. 7) and characterised as autotrophs (>10 $\mu \mathrm{m}$ in cell size) and heterotrophs (large copepods, small copepods and nauplii). Also shown are small autotrophic cells $(<10 \mu \mathrm{m})$, which dominated the plankton biomass in Godthåbsfjord (Fig. 7). Potential prey biomass (autotrophs $>10 \mu \mathrm{m}$ and heterotrophs) was highest in the inner part of Godthåbsfjord at Stn GF11 and lowest offshore at Stn FB2. Offshore, at Stns FB3-FB1, autotrophic prey $>10$ $\mu \mathrm{m}$ made up a large part of the available prey (73 $\pm 11 \%$ ) (Fig. 7 ). This was also true for the fjord Stns GF2 to GF5 and the inner part of Godthåbsfjord (GF11 and 12) with $80 \pm 1$ and $73 \pm 7 \%$, respectively, being autotrophic prey $>10 \mu \mathrm{m}$. At the outermost stations (FB5 to FB3.5), potential prey was dominated by heterotrophs, making up $69 \pm 15 \%$ of the total potential prey 

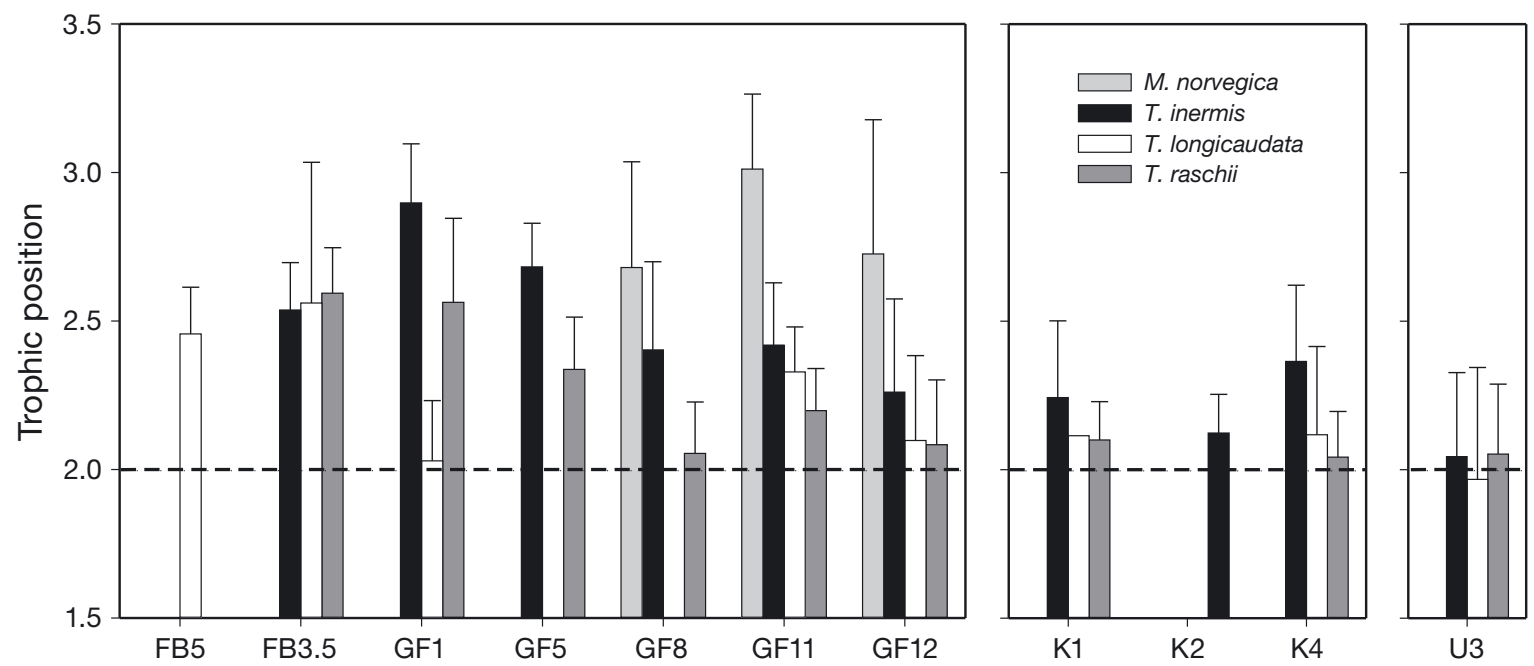

Fig. 6. Mean (+SD) trophic position of the 4 krill species (Meganyctiphanes norvegica, Thysanoessa inermis, T. longicaudata and T. raschii) found at the different stations (see Fig. 1). The dashed line indicates the trophic position of Calanus spp. used as the reference baseline

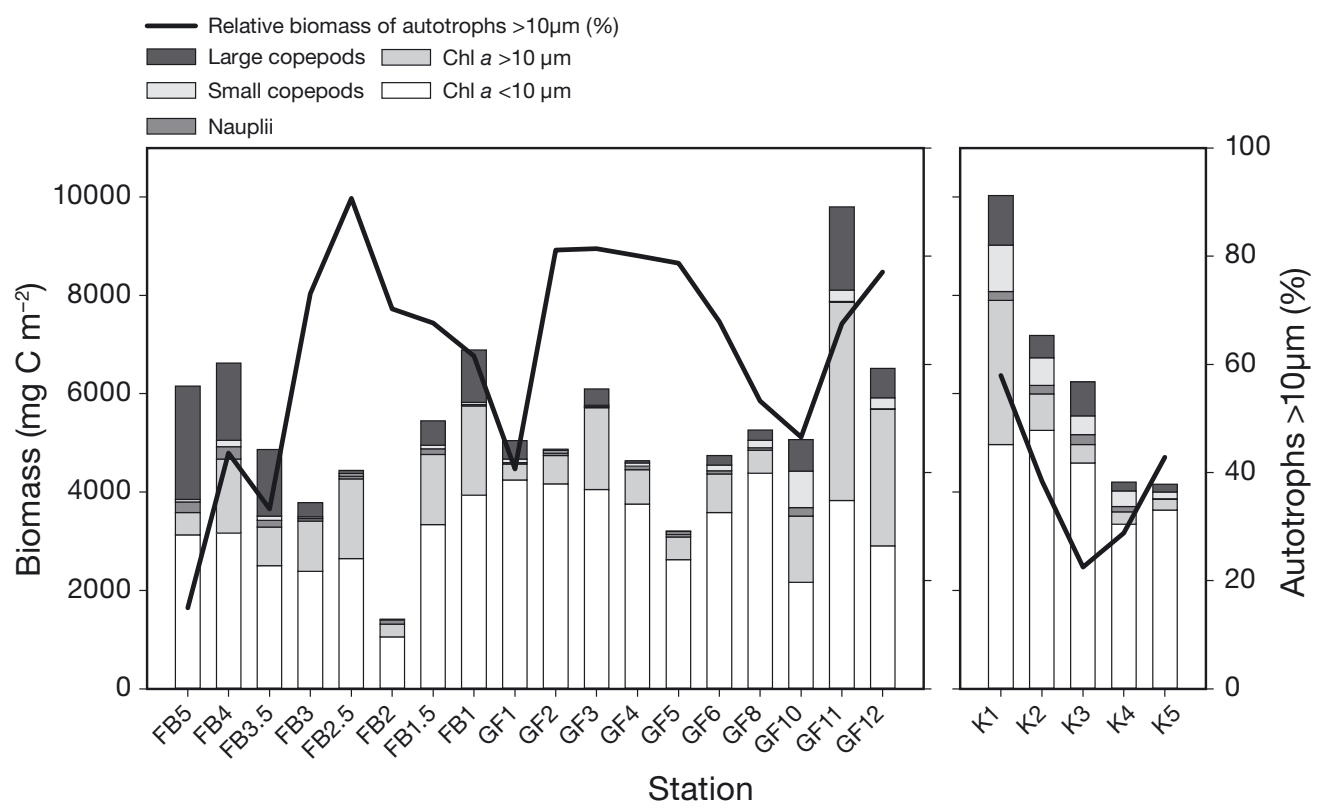

Fig. 7. Integrated biomass (mg C m${ }^{-2}$ ) of different plankton groups from Fyllas Bank (FB), Godthåbsfjord (GF) and Kapisigdlit (K). No data was available from Stn U3 (Umanap). Chlorophyll a (chl a) is presented as size fractions $>$ and $<10 \mu \mathrm{m}$, where only chl $a>10 \mu \mathrm{m}$ is considered as available autotrophic prey. Heterotrophic prey is presented as large copepods, small copepods and nauplii. Note that protozooplankton biomass is not included in the graph as no data was available. The line represents the relative contribution of autotrophic prey $>10 \mu \mathrm{m}$ compared with heterotrophic prey. For stations see Fig. 1

biomass. In Kapisigdlit, the highest potential prey biomass was found at the entrance of the fjord branch (Stn K1), with similar prey availability as in the inner part of Godthåbsfjord (Fig. 7). The potential prey biomass decreased towards the inner part of Kapisigdlit and, with the exception of the entrance Stn K1, the potential prey biomass was dominated by heterotrophic prey.

\section{DISCUSSION}

\section{Differences between species}

Here we present new insight regarding spatial differences in trophic position in coexisting krill species. We found differences between the 4 coexisting krill species, with the largest, Meganyctiphanes norve- 
gica, occupying the highest trophic position followed by Thysanoessa inermis, while T. longicaudata and $T$. raschii displayed a similar lower trophic position. These results agree with the classification of $M$. norvegica as carnivorous-omnivorous and T. inermis as omnivorous-carnivorous (terms defined by Søreide et al. 2013). T. longicaudata and T. raschiii were omnivorous to a lesser extent and could be described as herbivorous-omnivorous (Søreide et al. 2006, Søreide et al. 2013). However, there were spatial differences in trophic positions within species. T. longicaudata and T. raschii were both primarily herbivorous in the inner part of Godthåbsfjord, having the same trophic position as Calanus spp. ( $\mathrm{TP}=2$; Hobson \& Welch 1992, Søreide et al. 2006). However, both species reached trophic levels of $\sim 2.5$ in the offshore area, indicating a shift to a more mixed diet offshore. Here, the potential food was dominated by heterotrophic plankton. In contrast, inner Godthåbsfjord was dominated by autotrophs $>10 \mu \mathrm{m}$. The lower trophic positions occupied in the inner fjord indicate that krill likely grazed on the autotrophic rather than the heterotrophic prey here. Additionally, the offshore mesozooplankton community consisted of a higher fraction of copepod nauplii and copepods compared with inshore, which can be exploited by T. raschii (Agersted et al. 2011) and T. inermis (M. D. Agersted unpubl. data). Also, predation on smaller stages of the larger copepod species is likely to take place. In Kapisigdlit, autotrophic organisms dominated the plankton community, although with a higher proportion of smaller than larger cells dominating (Fig. 7). However, very high biomasses of protozooplankton have been reported in Kapisigdlit (Riisgaard et al. 2014), and Thysanoessa spp. might feed on these rather than the mesozooplankton, thus explaining the lower trophic position of the krill found here.

Petursdottir et al. (2008) found the $\delta^{15} \mathrm{~N}$ values of $M$. norvegica and C. finmarchicus collected from the Reykjanes Ridge in June to be almost one trophic level apart (Vander Zanden \& Rasmussen 2001, Post 2002, Søreide et al. 2006, Petursdottir et al. 2008), with $M$. norvegica having a trophic position of 2.9 and $C$. finmarchicus of 2 , which is similar to the values we found in our study. Petursdottir et al. (2008) also measured fatty acids in M. norvegica and found low levels of Calanus fatty acid trophic markers, but high amounts of 18:1(n-9) fatty acid, the latter indicating carnivorous feeding (Falk-Petersen et al. 2000, Dalsgaard et al. 2003). This suggests that C. finmarchicus is not the primary food item for $M$. norvegica, and other non-Calanus species might be a preferable prey item for $M$. norvegica in this area.
This result, however, does not affect the estimations of TP in our study as Calanus was used as a reference primary consumer for the entire food web (Vander Zanden \& Rasmussen 2001). Petursdottir et al. (2012) studied the trophic positions of pelagic species in the sub-Arctic Iceland Sea in August using phytoplankton fatty acid trophic markers. Here, M. norvegica had the lowest trophic position among the krill ( $\mathrm{TP}=$ 2.4), and a diet mainly consisting of phytoplankton and, to a lesser extent, Calanus spp. The other 2 species, T. longicaudata and T. inermis, occupied trophic positions of 2.5 to 2.7 and were concluded to predate on smaller copepods rather than on Calanus spp. (Petursdottir et al. 2012). Similar trophic positions for $T$. longicaudata and T. inermis have been found in other studies around Svalbard in the Barents Sea and the Arctic Ocean shelf-break region (Søreide et al. 2006, Tamelander et al. 2006), and also agree with our results for the 2 species in the mouth of Godthåbsfjord and in the offshore region. Based on results from the present and previous studies, we therefore conclude that the trophic position of the species might to a large extent depend on available prey, since krill can consume a wide range of prey types (Boyd et al. 1984, McClatchie 1985, Barange et al. 1991, Agersted et al. 2011).

\section{Differences in nutrient and food sources along the fjord}

We documented significant trends in the baseline isotope signals of Calanus spp. along the fjord, with an increase of both $\delta^{13} \mathrm{C}$ and $\delta^{15} \mathrm{~N}$ with distance from the shelf to the inner part of the fjord. Similar results were found by Holst Hansen et al. (2012) in the Godthåbsfjord area, where the inshore population of C. finmarchicus had higher $\delta^{15} \mathrm{~N}$ values than the offshore population. The differences observed in the stable isotope signals along the fjord could be due to different hydrography and nutrient availability in the different areas, thus affecting isotope fractionation (Vander Zanden \& Rasmussen 2001). The fjord area was divided into 4 different regions by Mortensen et al. (2011) based on differences in hydrography: (1) the continental slope, (2) the continental shelf, (3) the outer sill region and (4) the main fjord basin. The plankton communities have been found to be influenced by the oceanographic regions (Arendt et al. 2010, Calbet et al. 2011, Tang et al. 2011, Agersted \& Nielsen 2014), and these 4 regions were applied in Agersted \& Nielsen (2014) to identify different krill assemblages. 
Different circulation modes in Godthåbsfjord contribute to glacial ice melt (Mortensen et al. 2011), and increased freshwater addition to surface waters leads to an enhanced estuarine circulation (Kaartvedt \& Svendsen 1990, Rysgaard et al. 2003) and increased nutrient availability in the innermost part of the fjord. In addition, sub-glacial freshwater discharge (30 to $60 \mathrm{~m}$ depth) enhances upwelling in the bottom of the fjord (Mortensen et al. 2013), but on the other hand, leads to stratification of the main fjord basin, preventing new supply of nutrients from deeper waters (Dziallas et al. 2013). These factors would explain the high nitrate concentrations we found in the innermost part of the fjord and the low values within the fjord basin, whereas nutrient depletion offshore indicates post-bloom conditions. Besides, nitrate resulting from nitrification-denitrification inside semienclosed systems, such as estuaries, has been reported to have higher $\delta^{15} \mathrm{~N}$ values than nitrate from marine waters (Alkhatib et al. 2012). Increased nitrate supply and local nitrogen transformations would thus lead to changes in the $\delta^{15} \mathrm{~N}$ baseline signal in Calanus spp., where we documented the highest $\delta^{15} \mathrm{~N}$ inshore and the lowest offshore. From data derived from the same cruise as the present study, Calbet et al. (2011) additionally showed that nitrogen availability reflects the composition and distribution of the phytoplankton communities. In the inner fjord, high concentrations of fast-growing large diatom cells were found, whereas small, less-abundant cells were found in the mouth of the main fjord and in Kapisgdlit (Calbet et al. 2011). Similar to Calbet et al. (2011), Arendt et al. (2010) also found a dominance of large diatoms in the innermost part of Godthåbsfjord in May 2006, whereas other centric diatoms and the colonial haptophyte Phaeocystis spp. dominated in the rest of the fjord and in the offshore waters.

Differences in $\delta^{13} \mathrm{C}$ in the baseline signal indicate different food sources in the different areas (Perry et al. 1999, Søreide et al. 2006). Diatoms have been found to have high $\delta^{13} \mathrm{C}$ values compared with nanoplankton (Gearing et al. 1984). Fry \& Wainright (1991) also found fast-growing diatoms at Georges Bank to have high values of $\delta^{13} \mathrm{C}$ compared with other phytoplankton. This corresponds with the phytoplankton community (Calbet et al. 2011) and the high values of $\delta^{13} \mathrm{C}$ in Calanus spp. found in inner Godthåbsfjord in the present study.

Holst Hansen et al. (2012) did not find any difference in $\delta^{13} \mathrm{C}$ between inshore and offshore populations of C. finmarchicus from the Godthåbsfjord area in June and July 2010. Differences between our study and the study by Holst Hansen et al. (2012) in $\delta^{13} \mathrm{C}$ inshore versus offshore could be due to different sampling times (June 2010 in our study and June and July 2010 in the latter). Rapid changes in stable isotope signatures of plankton, along with changes in the sources of nutrients and prey, have been reported in other studies (Goering et al. 1990, Rolff 2000, Bode \& Alvarez-Ossorio 2004). Therefore, any differences observed between the 2 studies could be due to a change in the phytoplankton community (Gearing et al. 1984, Fry \& Wainright 1991) or to an increase in the relative contribution of other prey items, i.e. protozoans, as documented in the Kapisigdlit fjord branch (Riisgaard et al. 2014). In contrast to Calanus, krill species did not show clear spatial patterns in $\delta^{13} \mathrm{C}$, a feature that can be attributed to their greater mobility and feeding plasticity, which allows them to integrate different food items.

\section{Trophic position in relation to size}

In general, the trophic position of krill species increased with length. Our results confirm the overall increase of TP with body size as found for marine communities of fish and benthic invertebrates (Jennings et al. 2001, Jennings et al. 2002). However, this increase of TP was only significant when the largest species $M$. norvegica was included. Yet, an ontogenetic shift in diet in krill has been found in other studies. In spring and autumn, medium-sized specimens (10 to $19 \mathrm{~mm}$ ) of $T$. inermis were predominantly herbivorous or herbivorous-omnivorous, whereas larger T. inermis (> $22 \mathrm{~mm}$ ) were carnivorous (Søreide et al. 2006). Also, Polito et al. (2013) found an ontogenetic change in trophic level of the Antarctic krill species Euphausia superba. Adults had higher and more variable $\delta^{15} \mathrm{~N}$ values but consistent $\delta^{13} \mathrm{C}$ compared with juveniles, indicating that both adults and juveniles were feeding on phytoplankton, but the adults also fed on prey of higher trophic levels (Polito et al. 2013). Stowasser et al. (2012) also reported a positive and significant correlation between $\delta^{15} \mathrm{~N}$ values and body mass of E. superba. In contrast, Park et al. (2011) found significantly lower $\delta^{15} \mathrm{~N}$ values in adults of the krill Euphausia pacifica compared with juveniles. This was explained by the adults shifting to a more detritivorous diet containing carcasses of the copepod Neocalanus cristatus. Krill larvae are found to be herbivorous and to some extent omnivorous depending on season and species (Daly 1990, Frazer 1996, Meyer et al. 2002, Schmidt et al. 2003), supporting the general observation of an ontogenetic increase in trophic position. 


\section{The paradox of the krill}

Krill have a prey-size spectrum that spans several trophic levels, as indicated by the trophic overlap in stable isotopes documented here. A wide prey-size spectrum can be an advantage when species feeding on the same prey coexist, since this will lower interspecific competition. Another adaptation enabling coexistence is differences in behaviour such as diel vertical migration patterns and vertical spatial partitioning (Barange 1990, Barange et al. 1991). The ability of krill to utilise prey that occurs in different depth strata might also be a mechanism that reduces interspecific competition and thereby makes coexistence possible. In addition, Falk-Petersen et al. (2000) found that lipid dynamics are closely related to the different life cycle strategies of krill species, and makes it possible for the different species to utilise different ecological niches.

Agersted \& Nielsen (2014) found 4 krill species in Godthåbsfjord. There was spatial overlap between species, but different species dominated inshore and offshore. According to 'the competitive exclusion principle', 'complete competitors cannot coexist' (Hardin 1960). In other words, 2 species competing for the same resources will not be able to coexist if other ecological factors are constant, and interspecific competition will lead to either extinction of one species or the species occupying different ecological niches (Hardin 1960). Krill species in Godthåbsfjord have spatial overlap but different species dominate in different areas. Therefore, coexistence of several krill species in the fjord is possible. We therefore suggest that limited interaction among species, differences in behaviour and life cycle strategies, a wide prey-size spectrum and high productivity in the fjord resolve the paradox of the krill, and explain how these closely related species can coexist.

Acknowledgements. We thank the captain and crew on board R/V 'Dana' for good cooperation and our colleagues on board for their help and support. We also acknowledge the Greenland Institute of Natural Resources for good support and logistics, and A.F. Lamas (IEO) for sample preparation for isotopic analysis. Isotopic determinations were made by the Servicio de Apoyo a la Investigación (SAI) of the University of A Coruña (Spain). This project (BOFYGO) was funded by the Danish Centre for Marine Research, DCH. The research leading to these results has received funding from the European Union Seventh Framework Programme project EURO-BASIN (ENV.2010.2.2.1-1) under grant agreement no. 264933 and the Greenland Climate Research Centre (project 6505).

\section{LITERATURE CITED}

Agersted MD, Nielsen TG (2014) Krill diversity and population structure along the sub-Arctic Godthåbsfjord, SW Greenland. J Plankton Res 36:800-815

Agersted MD, Nielsen TG, Munk P, Vismann B, Arendt KE (2011) The functional biology and trophic role of krill (Thysanoessa raschii) in a Greenlandic fjord. Mar Biol 158:1387-1402

Alkhatib M, Lehmann MF, del Giorgio PA (2012) The nitrogen isotope effect of benthic remineralization-nitrification-denitrification coupling in an estuarine environment. Biogeosciences 9:1633-1646

Arendt KE, Nielsen TG, Rysgaard S, Tönnesson K (2010) Differences in plankton community structure along the Godthåbsfjord, from the Greenland Ice Sheet to offshore waters. Mar Ecol Prog Ser 401:49-62

Båmstedt U, Gifford DJ, Irigoien X, Atkinson A, Roman M (2000) Feeding. In: Harris RP, Wiebe PH, Lenz J, Skjoldal HR, Huntley M (eds) ICES zooplankton methodology manual. Academic Press, London, p 297-399

Barange M (1990) Vertical migration and habitat partitioning of six euphausiid species in the northern Benguela upwelling system. J Plankton Res 12:1223-1237

Barange M, Gibbons MJ, Carola M (1991) Diet and feeding of Euphausia hanseni and Nematoscelis megalops (Euphausiacea) in the northern Benguela Current: ecological significance of vertical space partitioning. Mar Ecol Prog Ser 73:173-181

$>$ Berkes F (1976) Ecology of euphausiids in the Gulf of St. Lawrence. J Fish Res Board Can 33:1894-1905

Bicknell AW, Campbell M, Knight ME, Bilton DT, Newton J, Votier SC (2011) Effects of formalin preservation on stable carbon and nitrogen isotope signatures in Calanoid copepods: implications for the use of Continuous Plankton Recorder Survey samples in stable isotope analyses. Rapid Commun Mass Spectrom 25:1794-1800

$>$ Bode A, Alvarez-Ossorio MT (2004) Taxonomic versus trophic structure of mesozooplankton: a seasonal study of species succession and stable carbon and nitrogen isotopes in a coastal upwelling ecosystem. ICES J Mar Sci 61:563-571

Boyd CM, Heyraud M, Boyd CN (1984) Feeding of the Antarctic krill Euphausisa superba. J Crustac Biol 14: 123-141

Calbet A, Riisgaard K, Saiz E, Zamora S, Stedmon C, Nielsen TG (2011) Phytoplankton growth and microzooplankton grazing along a sub-Arctic fjord (Godthåbsfjord, west Greenland). Mar Ecol Prog Ser 442:11-22

> Chiba S, Sugisaki H, Kuwata A, Tadokoro K, Kobari T, Yamaguchi A, Mackas DL (2012) Pan-North Pacific comparison of long-term variation in Neocalanus copepods based on stable isotope analysis. Prog Oceanogr 97: 63-75

- Conover RJ (1988) Comparative life histories in the genera Calanus and Neocalanus in high latitudes of the northern hemisphere. Hydrobiologia 167-168:127-142

> Dalsgaard J, St John M, Kattner G, Muller-Navarra D, Hagen W (2003) Fatty acid trophic markers in the pelagic marine environment. Adv Mar Biol 46:225-340

$>$ Daly KL (1990) Overwintering development, growth, and feeding of larval Euphausia superba in the Antarctic marginal ice zone. Limnol Oceanogr 35:1564-1576

> Dziallas C, Grossart HP, Tang KW, Nielsen TG (2013) Distinct communities of free-living and copepod-associated 
microorganisms along a salinity gradient in Godthåbsfjord, West Greenland. Arctic Antarctic Alpine Res 45:471-480

Falk-Petersen S, Hagen W, Kattner G, Clarke A, Sargent J (2000) Lipids, trophic relationships, and biodiversity in Arctic and Antarctic krill. Can J Fish Aquat Sci 57:178-191

Falk-Petersen S, Mayzaud P, Kattner G, Sargent JR (2009) Lipids and life strategy of Arctic Calanus. Mar Biol Res 5: 18-39

> France RL (1995) Differentiation between littoral and pelagic food webs in lakes using stable carbon isotopes. Limnol Oceanogr 40:1310-1313

- Frazer TK (1996) Stable isotope composition $\left(\delta^{13} \mathrm{C}\right.$ and $\left.\delta^{15} \mathrm{~N}\right)$ of larval krill, Euphausia superba, and two of its potential food sources in winter. J Plankton Res 18:1413-1426

Fry B (1988) Food web structure on Georges Bank from stable C, N and S isotopic compositions. Limnol Oceanogr 33:1182-1190

Fry B, Sherr EB (1984) $\delta^{13} \mathrm{C}$ measurements as indicators of carbon flow in marine and freshwater ecosystems. Contrib Mar Sci 27:13-47

> Fry B, Wainright SC (1991) Diatom sources of ${ }^{13} \mathrm{C}$-rich carbon in marine food webs. Mar Ecol Prog Ser 76:149-157

Gearing JN, Gearing PJ, Rudnick DT, Requejo AG, Hutchins MJ (1984) Isotopic variability of organic carbon in a phytoplankton-based, temperate estuary. Geochim Cosmochim Acta 48:1089-1098

> Goering J, Alexander V, Haubenstock N (1990) Seasonal variability of stable carbon and nitrogen isotope ratios of organisms in a North Pacific Bay. Estuar Coast Shelf Sci 30:239-260

> González HE (1992) The distribution and abundance of krill faecal material and oval pellets in the Scotia and Weddell Seas (Antarctica) and their role in particle flux. Polar Biol 12:81-91

Hansen HP, Koroleff F (1999) Determination of nutrients. In: Grasshoff K, Kremling K, Ehrhardt M (eds) Methods of seawater analysis, 3rd edn. Wiley-VCH, Weinheim, p 159-228

> Hardin G (1960) The competitive exclusion principle. Science 131:1292-1297

> Hobson KA, Welch HE (1992) Determination of trophic relationships within a high Arctic marine food web using $\delta^{13} \mathrm{C}$ and $\delta^{15} \mathrm{~N}$ analysis. Mar Ecol Prog Ser 84:9-18

> Hobson KA, Piatt JF, Pitocchelli J (1994) Using stable isotopes to determine seabird trophic relationships. J Anim Ecol 63:786-798

> Holst Hansen J, Berg Hedeholm R, Sünksen K, Tang Christensen J, Grønkjær P (2012) Spatial variability of carbon $\left(\delta^{13} \mathrm{C}\right)$ and nitrogen $\left(\delta^{15} \mathrm{~N}\right)$ stable isotope ratios in an Arctic marine food web. Mar Ecol Prog Ser 467:47-59

Hutchinson GE (1961) The paradox of the plankton. Am Nat 95:137-145

Jennings S, Pinnegar JK, Polunin NVC, Boon TW (2001) Weak cross-species relationships between body size and trophic level belie powerful size-based trophic structuring in fish communities. J Anim Ecol 70:934-944

> Jennings S, Pinnegar JK, Polunin NVC, Warr KJ (2002) Linking size-based and trophic analyses of benthic community structure. Mar Ecol Prog Ser 226:77-85

Jespersen AM, Christoffersen K (1987) Measurements of chlorophyll a from phytoplankton using ethanol as extraction solvent. Arch Hydrobiol 109:445-454

Kaartvedt S, Svendsen H (1990) Impact of freshwater runoff on physical oceanography and plankton distribution in a western Norwegian fjord: an experiment with a controlled discharge from hydroelectric power plant. Estuar Coast Shelf Sci 31:381-395

Karlson K, Båmstedt U (1994) Planktivorous predation on copepods. Evaluation of mandible remains in predator guts as a quantitative estimate of predation. Mar Ecol Prog Ser 108:79-89

> Kiørboe T (2013) Zooplankton body composition. Limnol Oceanogr 58:1843-1850

Levinsen H, Jefferson TT, Nielsen TG, Hansen BW (2000) On the trophic coupling between protists and copepods in arctic marine ecosystems. Mar Ecol Prog Ser 204: $65-77$

Mauchline J, Fisher LR (1969) The biology of euphausiids. Adv Mar Biol 7:1-454

McClatchie S (1985) Feeding behavior in Meganyctiphanes norvegica (M. Sars) (Crustacea, Euphausiacea). J Exp Mar Biol Ecol 86:271-284

Meyer B, Atkinson A, Stubing D, Oettl B, Hagen W, Bathmann UV (2002) Feeding and energy budgets of Antarctic krill Euphausia superba at the onset of winter - I. Furcilia III larvae. Limnol Oceanogr 47:943-952

- Miyazaki T, Tainaka Ki, Togashi T, Suzuki T, Yoshimura J (2006) Spatial coexistence of phytoplankton species in ecological timescale. Popul Ecol 48:107-112

Mortensen J, Lennert K, Bendtsen J, Rysgaard S (2011) Heat sources for glacial melt in a sub-Arctic fjord (Godthåbsfjord) in contact with the Greenland Ice Sheet. J Geophys Res C 116:C01013, doi:01010.01029/02010JC006528

> Mortensen J, Bendtsen J, Motyka RJ, Lennert K, Truffer M, Fahnestock M, Rysgaard S (2013) On the seasonal freshwater stratification in the proximity of fast-flowing tidewater outlet glaciers in a sub-Arctic sill fjord. J Geophys Re: Oceans 118:1382-1395, doi:10:1002/jcrc.20134

> Onsrud MSR, Kaartvedt S, Rostad A, Klevjer TA (2004) Vertical distribution and feeding patterns in fish foraging on the krill Meganyctiphanes norvegica. ICES J Mar Sci 61: 1278-1290

Park JI, Kang CK, Suh HL (2011) Ontogenetic diet shift in the euphausiid Euphausia pacifica quantified using stable isotope analysis. Mar Ecol Prog Ser 429:103-109

Perry RI, Thompson PA, Mackas DL, Harrison PJ, Yelland DR (1999) Stable carbon isotopes as pelagic food web tracers in adjacent shelf and slope regions off British Columbia, Canada. Can J Fish Aquat Sci 56:2477-2486

Peterson BJ, Fry B (1987) Stable isotopes in ecosystem studies. Annu Rev Ecol Syst 18:293-320

> Petursdottir H, Gislason A, Falk-Petersen S, Hop H, Svavarsson J (2008) Trophic interactions of the pelagic ecosystem over the Reykjanes Ridge as evaluated by fatty acid and stable isotope analyses. Deep-Sea Res II 55:83-93

Petursdottir H, Falk-Petersen S, Gislason A (2012) Trophic interaction of meso- and macrozooplankton and fish in the Iceland Sea as evaluated by fatty acid and stable isotope analysis. ICES J Mar Sci 69:1277-1288

> Polito MJ, Reiss CS, Trivelpiece WZ, Patterson WP, Emslie SD (2013) Stable isotopes identify an ontogenetic niche expansion in Antarctic krill (Euphausia superba) from the South Shetland Islands, Antarctica. Mar Biol 160: 1311-1323

> Post DM (2002) Using stable isotopes to estimate trophic position: models, methods, and assumptions. Ecology 83: 703-718

Rau GH, Ohman MD, Pierrot-Bults A (2003) Linking nitrogen dynamics to climate variability off central California: 
a 51 year record based on ${ }^{15} \mathrm{~N} /{ }^{14} \mathrm{~N}$ in CalCOFI zooplankton. Deep-Sea Res II 50:2431-2447

Riisgaard K, Swalethorp R, Kjellerup S, Juul-Pedersen T, Nielsen TG (2014) Trophic role and top-down control of a subarctic protozooplankton community. Mar Ecol Prog Ser 500:67-82

Rolff C (2000) Seasonal variation in $\delta^{13} \mathrm{C}$ and $\delta^{15} \mathrm{~N}$ of sizefractionated plankton at a coastal station in the northern Baltic proper. Mar Ecol Prog Ser 203:47-65

Rosing-Asvid A, Hedeholm R, Arendt KE, Fort J, Robertson GJ (2013) Winter diet of the little auk (Alle alle) in the Northwest Atlantic. Polar Biol 36:1601-1608

Rysgaard S, Vang T, Stjernholm M, Rasmussen B, Windelin A, Kiilsholm S (2003) Physical conditions, carbon transport, and climate change impacts in a Northeast Greenland fjord. Arct Antarct Alp Res 35:301-312

Sarakinos HC, Johnson ML, Vander Zanden MJ (2002) A synthesis of tissue-preservation effects on carbon and nitrogen stable isotope signatures. Can J Zool 80:381-387

Sargent JR, Falk-Petersen S (1981) Ecological investigations on the zooplankton community in Balsfjorden, northern Norway: lipids and fatty acids in Meganyctiphanes norvegica, Thysanoessa raschi and $T$. inermis during mid-winter. Mar Biol 62:131-137

Schmidt K (2010) Food and feeding in northern krill (Meganyctiphanes norvegica Sars). In: Tarling GA (ed) Advances in marine biology: biology of northern krill. Academic Press, London, p 127-171

Schmidt K, Atkinson A, Stubing D, McClelland JW, Montoya JP, Voss M (2003) Trophic relationships among Southern Ocean copepods and krill: some uses and limitations of a stable isotope approach. Limnol Oceanogr 48: $277-289$

Schmidt K, McClelland JW, Mente E, Montoya JP, Atkinson A, Voss M (2004) Trophic-level interpretation based on $\delta^{15} \mathrm{~N}$ values: implications of tissue-specific fractionation and amino acid composition. Mar Ecol Prog Ser 266:43-58

Søreide JE, Hop H, Carroll ML, Falk-Petersen S, Hegseth EN (2006) Seasonal food web structures and sympagic-pelagic coupling in the European Arctic

Editorial responsibility: Edward Durbin,

Narragansett, Rhode Island, USA revealed by stable isotopes and a two-source food web model. Prog Oceanogr 71:59-87

Søreide JE, Falk-Petersen S, Hegseth EN, Hop H, Carroll ML, Hobson KA, Blachowiak-Samolyk K (2008) Seasonal feeding strategies of Calanus in the high-Arctic Svalbard region. Deep-Sea Res II 55:2225-2244

> Søreide JE, Carroll ML, Hop H, Ambrose WG Jr, Hegseth EN, Falk-Petersen S (2013) Sympagic-pelagic-benthic coupling in Arctic and Atlantic waters around Svalbard revealed by stable isotopic and fatty acid tracers. Mar Biol Res 9:831-850

> Stowasser G, Atkinson A, McGill RAR, Phillips RA, Collins MA, Pond DW (2012) Food web dynamics in the Scotia Sea in summer: a stable isotope study. Deep-Sea Res II 59-60:208-221

Sutherland DA, Pickart RS (2008) The east Greenland coastal current: structure, variability and forcing. Prog Oceanogr 78:58-77

Swalethorp R, Malanski E, Agersted MD, Nielsen TG, Munk P (2014) Structuring of zooplankton and fish larvae assemblages in a freshwater-influenced Greenlandic fjord: influence from hydrography and prey availability. J Plankton Res, doi:10.1093/plankt/fbu09

Tamelander T, Renaud PE, Hop H, Carroll ML, Ambrose WG Jr, Hobson KA (2006) Trophic relationships and pelagic-benthic coupling during summer in the Barents Sea Marginal Ice Zone, revealed by stable carbon and nitrogen isotope measurements. Mar Ecol Prog Ser 310: $33-46$

Tang KW, Nielsen TG, Munk P, Mortensen J and others (2011) Metazooplankton community structure, feeding rate estimates, and hydrography in a meltwater-influenced Greenlandic fjord. Mar Ecol Prog Ser 434:77-90

Vander Zanden MJ, Rasmussen JB (2001) Variation in $\delta^{15} \mathrm{~N}$ and $\delta^{13} \mathrm{C}$ trophic fractionation: implications for aquatic food web studies. Limnol Oceanogr 46:2061-2066

Wiggert JD, Haskell AGE, Paffenhöfer GA, Hofmann EE, Klinck JM (2005) The role of feeding behavior in sustaining copepod populations in the tropical ocean. J Plankton Res 27:1013-1031

Submitted: March 14, 2014; Accepted: September 26, 2014 Proofs received from author(s): November 17, 2014 